\title{
Preliminary estimate of floods discharge in Brazil using Creager envelope curves
}

\section{Estimativa preliminar de vazões de cheias no Brasil usando curvas envoltórias de Creager}

\author{
Guilherme de Lima ${ }^{1}$, Silvana Susko Marcellini ${ }^{1}$, Charles Robert Neill ${ }^{2}$ and Márcio Ricardo Salla ${ }^{3}$ \\ ${ }^{1}$ NHC Brasil Consultores, São Paulo, SP, Brazil \\ ${ }^{2}$ Northwest Hydraulic Consultants, Edmonton, Alberta, Canada \\ ${ }^{3}$ Universidade Federal de Uberlândia, Uberlândia, MG, Brazil \\ E-mails: glima@nhcweb.com (GL), ssusko@nhcweb.com (SSM), cneill@nhcweb.com (CRN), marcio.salla@ufu.br (MRS)
}

Received: June 14, 2016 - Revised: September 11, 2016 - Accepted: September 27, 2016

\begin{abstract}
Hydrologic studies are essential for the design and safety of hydraulic structures. In the past, a number of empirical equations were developed to represent relationships between drainage areas and observed peak discharges. Although these empirical equations have not been used frequently to study peak discharges due to the use of more detailed and sophisticated analysis, they can be used to estimate reference values, especially in ungaged sites. The objective of this paper is to assess peak discharges observed in many regions in Brazil, estimate the 10,000-year discharges according the Guia para Cálculo de Cheia de Projeto de Vertedores from Eletrobrás and compare them to the Creager envelope curves. In this study we used the records of naturalized discharges for the period of 1931 to 2012 , for 131 hydroelectric projects selected in the main river basins in Brazil, using the official data published by the Operador Nacional do Sistema Elétrico (ONS) for the Sistema Interligado Nacional (SIN). The results presented in this paper show that it is possible to use the Creager envelope curves as a preliminary estimate of the design floods in Brazil. Generally, values of the Greager C coefficient between 60 and 100 are recommended for a preliminary estimate of a range of maximum discharges within drainage areas bigger than $10,000 \mathrm{~km}^{2}$. The results can be used in the preliminary estimate of maximum discharges and 10,000-year discharges for sites with no data using $\mathrm{C}$ values obtained from areas with enough data in the same river basin and with similar physical characteristics.
\end{abstract}

Keywords: Peak discharge; 10,000-year discharges; Creager envelope curves.

\section{RESUMO}

Os estudos hidrológicos de cheia são essenciais para o dimensionamento e segurança das obras hidráulicas. No passado uma série de fórmulas empíricas foram desenvolvidas para descrever a relação entre a área de drenagem e as vazões máximas de cheia observadas. Embora as fórmulas empíricas não sejam empregadas com grande frequência em estudos de cheias, em virtude do emprego de métodos mais sofisticadas e detalhados, elas podem ser utilizadas para determinar valores de referência, principalmente em locais com poucos dados hidrológicos. O presente artigo analisou as maiores vazões de cheia observadas em diversas regiões do Brasil, estimou as vazões decamilenares segundo o procedimento do Guia para Cálculo de Cheia de Projeto de Vertedores da Eletrobrás e comparou-as com a curva envoltória de Creager. Foram utilizadas as séries de vazões naturais reconstituídas, compreendidas entre 1931 a 2012, para 131 aproveitamentos hidrelétricos previamente selecionados nas principais bacias hidrográficas do Brasil, disponibilizadas pelo Operador Nacional do Sistema Elétrico (ONS), para o Sistema Interligado Nacional (SIN). Os resultados apresentados neste artigo mostram que é possível utilizar as curvas envoltórias de Creager como referência preliminar na estimativa de vazões de cheias para projetos. No Brasil, de maneira geral, valores do coeficiente C de Creager entre 60 e 100 são recomendados na determinação preliminar de um intervalo de vazões máximas em locais com áreas de drenagem superiores a $10.000 \mathrm{~km}^{2}$. Os resultados podem ser usados na estimativa preliminar de uma vazão máxima e da vazão decamilenar para um local sem dados, usando valores de $C$ obtidos em um local com dados na mesma região hidrográfica com características físicas similares.

Palavras-chave: Vazão de cheia; Vazão decamilenar; Curva envoltória de Creager. 


\section{INTRODUCTION}

Hydrologic studies of floods are essential for the dimensioning and security of hydraulic works. In the past, empirical formulas were developed to describe the relationship between drainage areas and observed maximum discharges. Among various formulas, one the most well-known is by Creager, Justin and Hinds (1945) as quoted by Neill (1986). The envelope curve of Creager provides an estimate of maximum expected discharge as a function of drainage area, and is based on a large number of exceptional floods in the United States and some in other countries, including the Amazon River. Other works that deserve mention are the pioneering work by Jarvis (1925), which involved a study based on maximum recorded floods at 888 gauging stations in the United States, and Francou and Rodier (1967) which applied the envelope curve method on a world scale. There are also studies by Crippen (1982) for American basins, Neill (1986) for basins in Canada, Kaviski (1993) for the southern region of Brazil, Herschy (2003) for various regions of the world, Castellarin (2007) for a region of Italy, and Coelho Filho, Naghettini and Pinto (2011) for the State of Minas Gerais in Brazil, among others.

Although empirical formulas relating maximum observed discharges to drainage area may not be employed with great frequency, they can be used as reference values for preliminary estimates of project floods, mainly for places where there are few or no data. In this context, the present article presents a study developed to evaluate the behaviour of the greatest flood discharges measured in various regions of Brazil and of estimated 10,000-year floods in relation to the envelope curves of Creager, Justin and Hinds (1945), and to verify the applicability of this method to preliminary estimates of flood discharges for pr006Fjects in Brazil.

\section{METHODOLOGY}

The study was based on the following steps: selection of locations with available consistent historic series of daily discharges: definition of criteria for selecting series of maximum daily discharges; frequency analysis of maximum daily discharges and estimation of 10,000-year values; and assessment of the behaviour of observed and 10,000-year floods in Brazil in relation to the envelope curves defined by Creager, Justin and Hinds (1945).

\section{Selection of locations with available consistent historic series of daily discharges}

In order to evaluate the peaks of large floods recorded in Brazil and estimate the 10,000-year discharges used in spillway projects based on the procedure of the Electrobas Guide for Calculating Spillway Project Floods (ELETROBRÁS, 1987), we used a series of natural discharges reconstituted from hydro-electric facilities in the principal hydrographic basins, made available by the ONS for the SIN. These series were used according to availability, area of coverage and consistency. The use of reconstituted natural discharges is important for recovering the natural characteristics of discharge magnitude and variability whre they have been altered by human action. However, the process of reconstituting discharge series is subject to various uncertainties. For this study
131 locations were selected with data series from 1931 to 2012, and with drainage areas from 305 to $988,873 \mathrm{~km}^{2}$. Figure 1 shows the spatial distribution of the pre-selected locations in the principal hydrographic basins of Brazil.

\section{Definition of criteria for selecting maximum daily discharges}

For selecting the maximum observed daily discharges the following criteria and procedures were adopted:

(i) Selection of locations with historical series of at least 30 years of observation;

(ii) Selection of the maximum observed daily discharge for each location;

(iii) Calculation of the maximum instantaneous discharge from the maximum daily values using the Fuller formula (Equation 1):

$\mathrm{Q}_{\text {inst }}=\mathrm{Q}_{\text {máx }}\left(1+2.66 / \mathrm{A}^{0.3}\right)$

where Qinst and Qmax are the maximum instantaneous and observed average daily discharges and $A$ is the basin area in $\mathrm{km}^{2}$.

The Eletrobas Guide (ELETROBRÁS, 1987) recommends this formula. Analyses and discussions on the estimation of

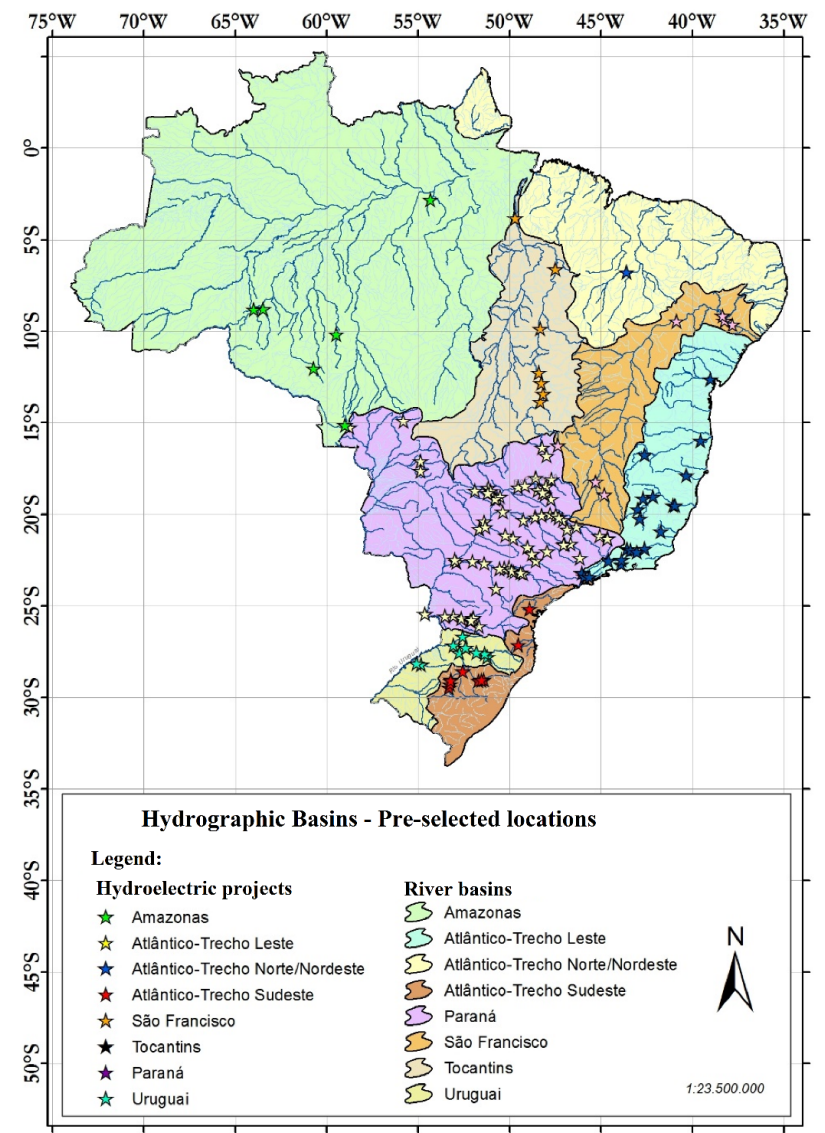

Figure 1. Spatial distribution of pre-selected locations in the principal hydrographic basins of Brazil. 
maximum instantaneous discharges can be found in Silva and Tucci (1998), Fill and Steiner (2003) and Sangal (1983).

The basic period of observed data is one day, that is, the discharges recorded in historical series represent a daily average of 2 readings. This interval is often insufficient in the case of basins with short times of concentration, so that it becomes necessary to estimate the maximum instantaneous discharges.

(iv) Calculation of specific discharges as Qinst/A.

\section{Frequency analysis of maximum daily discharge and estimation of 10,000-year discharges}

The following procedures were adopted to estimate 10,000-year discharges:

(i) For each gauged location, the maximum mean-daily discharges were selected for each year of the corresponding historical series of reconstituted natural discharges;

(ii) For each historical series of selected annual maximum daily discharges, a statistical summary was calculated representing the following variables to be used in frequency analysis: number of elements; average, maximum and minimum discharges; standard deviation; coefficients of asymmetry and kurtosis;

(iii) Checking of the maximum series for extreme events or "outliers" through Box-Plot analysis and the test suggested by Grubbs and Beck (1972);

(iv) Frequency analysis of maximum annual daily discharges to define the empirical probability distributions, using the plotting position suggested by Cunnane (1978). This was necessary to verify the trend of the series as related to the defined probability distribution;

(v) Adjusting the probability distribution of maximum annual daily discharges. The Eletrobras Guide for Spillway Project Floods (ELETROBRÁS, 1987) and the Manual of Studies of Water Availability for Hydroelectric Projects (ANA, 2009) present recommendations for selecting probability distributions for adjusting maximum discharges. The results of the studies and other investigations led to recommendation of the Exponential and Gumbel distributions, establishing in principle that the choice between them should be determined by the value attributed to sample asymmetry. The Eletrobras Guide recommends the exponential distribution when the asymmetry coefficient is greater than 1 . The ANA Manual recommends preferential use of the 2-parameter Exponential Distribution when the asymmetry coefficient exceeds 1.5, and the Gumbel Distribution when it is equal to or less than 1.5. For purposes of this work, the choice of distribution was based on visual analysis and the sample values of asymmetry coefficients. A 2-parameter exponential distribution was used for values between 1.0 and 2.5 , while the Gumbel distribution was used for values close to the lower limit of this interval. This step enabled estimation of the 10,000-year discharge for each selected station;

(vi) Obtaining the instantaneous 10,000-year discharge on the basis of the Fuller formula shown in Equation 1; (vii) Calculating the corresponding specific discharges by dividing by the basin area.

\section{Assessment of the behaviour of flood and 10,000 -year discharges in Brazil in relation to the envelope curves defined by Creager}

Maximum instantaneous discharges were determined for 131 locations with drainage areas varying from 305 to $988,873 \mathrm{~km}^{2}$. Only those series with a good adjustment of the probability distributions were considered, others were discarded, resulting in the selection of 114 hydroelectric locations.

The specific maximum daily and 10,000-year instantaneous values were compared with the envelope curves of Creager, Justin and Hinds (1945) using (Equation 2):

$Q_{\text {inst }}=1.303 C\left(\frac{A}{2.59}\right)^{\left(\frac{0.936}{\mathrm{~A}^{0.048}}\right)}$

where Qinst is the maximum instantaneous discharge (daily or 10,000 -year) in $\mathrm{m}^{3} / \mathrm{s} ; A$ is the basin hydrographic area in $\mathrm{km}^{2}$; and $C$ is the Creager coefficient. $C$ values of $100,60,30$ and 5 were used for this study.

Creager, Justin and Hinds (1945) used a great number of exceptional floods in U.S. rivers, and some from other countries, to analyze the relationship between drainage area and specific discharge. To represent this relationship, they adopted an empirical equation of double exponential form (Equation 2). The majority of the floods studied represent $C$ values between 30 and 100. An analysis of the Creager equation was made by Neill (1986).

\section{RESULTS AND DISCUSSION}

Figure 2 presents the specific discharges corresponding to instantaneous maximum and 10,000-year floods as estimated for the selected locations in Brazil, as a function of drainage area and the Creager envelope curves for $C$ values of 100, 60, 30 and 5 .

Figure 2 shows that specific discharges vary for a given drainage area, as was expected. For the analyzed data the variation is inversely proportional to drainage area. Generally, the larger basins are more homogeneous, while the smaller basins can have very different physical characteristics and land use, which could contribute to explaining this major variation for smaller drainage areas. For drainage areas above $10,000 \mathrm{~km}^{2}$ approximately, the upper limit of maximum flood discharges is close to the Creager envelope curve for $\mathrm{C}=100$. For lesser areas, however, the upper limit of maximum discharges is near or below the Creager curve for $\mathrm{C}=30$. This can be explained by the smaller number of locations with drainage areas less than $10,000 \mathrm{~km}^{2}$ (only $30 \%$ of the total) and also by the fact that generally, areas over $10,000 \mathrm{~km}^{2}$ have longer historical series. Therefore it is probable that for areas of less than $10,000 \mathrm{~km}^{2}$ the observed events don't correspond to maximum possible values (or that the analyzed historical series don't include extraordinary events). 


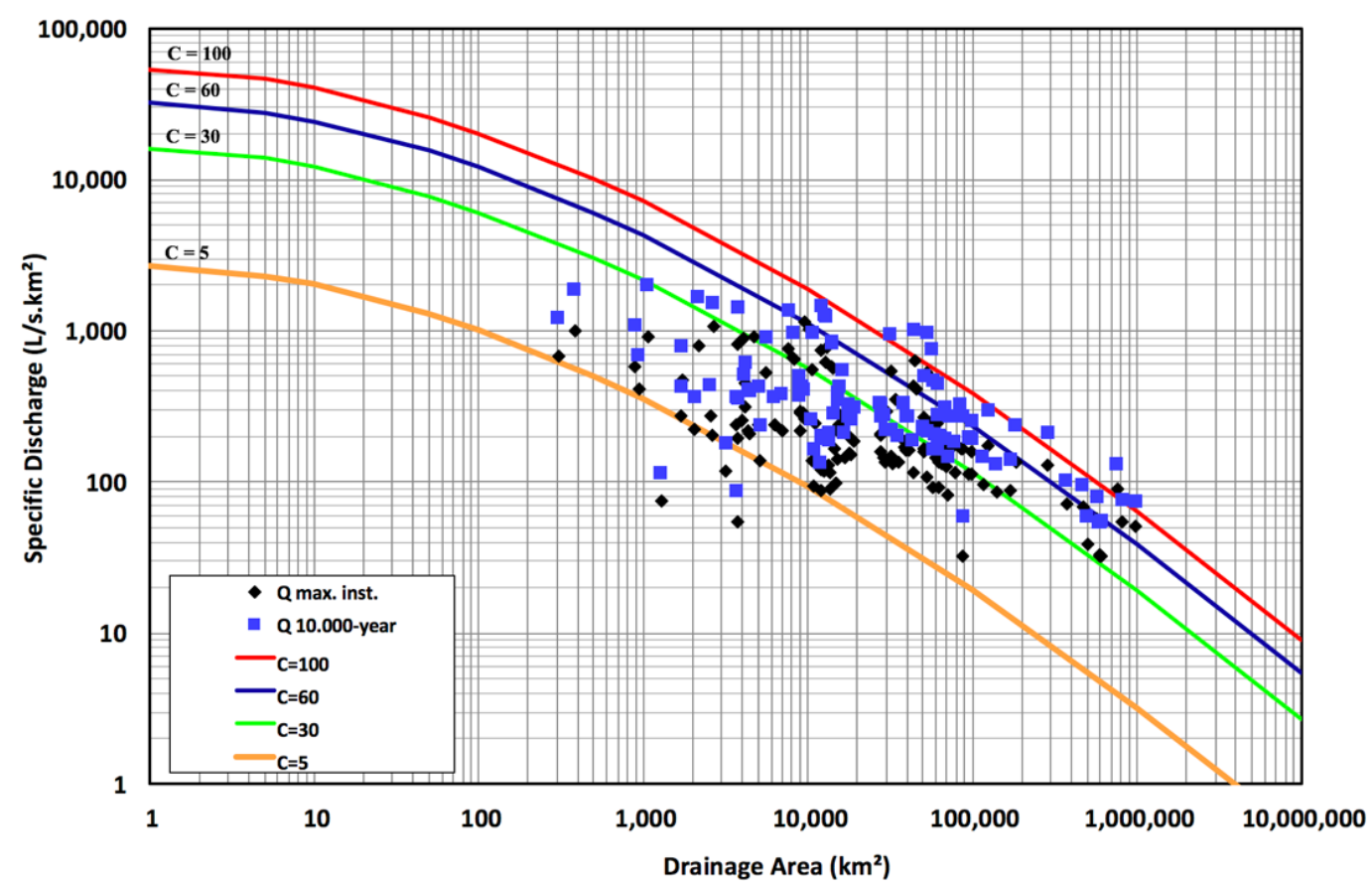

Figure 2. Specific flood and 10,000-year discharges and Creager envelope curves as functions of drainage area.

For 10,000-year discharges, values of $\mathrm{C}$ range up to 162. For areas less than $20,000 \mathrm{~km}^{2}$ approximately, $6.8 \%$ of the 10,000 -year discharges represent $C$ values over 60, 18.6\% between 30 and 60 , and $74.6 \%$ less than 30 . For areas between 20,000 and $100,000 \mathrm{~km}^{2}, 25.6 \%$ of the $\mathrm{C}$ values are above $60,53.8 \%$ between 30 and 60 , and $20.5 \%$ below 30 . For areas above $10,000 \mathrm{~km}^{2}, 56.3 \%$ of the $C$ values are above 60 and $43.7 \%$ are between 30 and 60 . The greatest $C$ values for 10,000-year floods are 162 for UHE Tucurui, 157 for UHE Foz de Chapeco (Rio Uruguai), 146 for UHE Ita (Rio Urugai) and 120 for UHE Estreito Tocantins (Rio Tocantins).

The authors analyzed separately the relationships between the values of $\mathrm{C}$ and the specific discharges of each studied region (Figure 2 ) in order to try to identify regional variations, but the analysis was inconclusive and would need a more detailed investigation and probably larger samples of locations and historical series.

Although empirical formulas are not presently used much in flood studies, because of more sophisticated and detailed methods like statistical and Probable Maximum Precipitation (PMP)/Probable Maximum Flood (PMF) studies, they can be used to obtain a reference value for maximum project floods. According to Neill (1986) envelopes of this kind can be considered as a useful practical tool for preliminary estimates and for checking estimates obtained from more detailed studies. Creager, Justin and Hinds (1945) used a large number of events considered extreme for the United States, and some events from other countries. The United States represents a large diversity of climate and soils, and its large floods embrace the majority of climate and soil conditions in other countries of the world except for monsoon regions. Creager's upper envelope curve has a C coefficient of 100 , but many points lie above this curve. Costa and Jarrett (2008) show that extreme events can have $\mathrm{C}$ varying from 100 to 200 for drainage basins with areas of less than $1,000 \mathrm{~km}^{2}$. For Canada, extreme event data analyzed by Neill (1986) showed that the upper envelope curve corresponded to a $\mathrm{C}$ value of less than 50 .

For Brazil, flood discharges for drainage areas above $10,000 \mathrm{~km}^{2}$ are near the envelope curve with $\mathrm{C}=100$. For smaller areas it seems that the maximum events, generally, also have an approximate upper limit of $C=100$, however this hypothesis needs to be confirmed through complementary studies. For 10,000-year floods, $C$ values up to 162 were obtained. Other studies used other envelope curves, like Francou and Rodier (1967) and Herschy (2003), to verify the results obtained with the Creager curves.

As a practical example, in 2014 the maximum discharge recorded at UHE San Antonio, with a drainage area of $988,873 \mathrm{~km}^{2}$, was $58,920 \mathrm{~m}^{3} / \mathrm{s}$, surpassing the maximum historical value of $48,565 \mathrm{~m}^{3} / \mathrm{s}$ in 1984 and representing a Creager $\mathrm{C}$ of 95.5 . The estimated 10,000-year maximum is $73,860 \mathrm{~m}^{3} / \mathrm{s}(\mathrm{C}=115)$. According to project information, the spillway was tested for a discharge of up to $84,000 \mathrm{~m}^{3} / \mathrm{s}(\mathrm{C}=130)$. These values could be used as a preliminary initial reference for other hydroelectric projects in the Amazon River basin (Figure 2).

At present the project flood for hydroelectric spillways is determined in most cases using probability studies based on the Eletrobas Guide of 1987. Some problems related to probability studies of extreme events are as follows:

(i) The period of record of annual flood data is generally quite short, barely a few decades, and the variability of maximum discharges is often high. Even assuming that 
the climate and/or surface drainage characteristics are stationary, there are uncertainties about the reliability of the data base, the representativeness in the long term of the period of record, and the statistical distributions suitable for adjustment and extrapolation, which means that the confidence limits on a 1,000-year estimate, for example, are generally so large that their reliability is quite low;

(ii) Land use in many Brazilian hydrographic basins changes considerably over time. Then it is questionable whether the surface runoff, as recorded in a series of discharges, represents a stationary series. Besides, the climate is subject to long-period fluctuations, as well as a trend associated with global warming;

(iii) Even when it is possible to obtain more confident extrapolations of rainfall data and use them to model discharges, it is difficult to relate the frequencies of output (spillway design flood) with the frequencies of input (project rainfall).

The authors suggest that future studies make a revision of the Guide and propose updates based on practical experience from recent projects and on the state of knowledge. An important question is the possibility of of estimating the spillway design flood based on an estimate of the PMP (Probable Maximum Precipitation) and PMF (Probable Maximum Flood) instead of only using a probability study of extreme events.

\section{CONCLUSIONS}

This article analyzed the greatest flood discharges for 131 stations whose discharge series are available through ONS for various regions of Brazil, as well as the 10,000-year discharges estimated for spillway projects according to the procedure of the Eletrobas Guide (ELETROBRÁS, 1987), and compared these discharges with the envelope curves developed by Creager, Justin and Hinds (1945).

The results show that it is possible to use the Creager envelope as a reference for estimating flood discharges for projects in Brazil. Values of the coefficient $C$ between 60 and 100 are recommended for preliminary determination of the range of maximum discharges in drainage areas exceeding 10,000 $\mathrm{km}^{2}$. The results can also be used for preliminary estimates for a location without data, using $\mathrm{C}$ values obtained from a location with data in the same hydrographic region with similar physical characteristics. For example: the $\mathrm{C}$ value obtained for the UHE Santo Antonio project ( $\mathrm{C}$ between 95.5 and 115) can be used for preliminary estimation of the maximum and 10,000-year discharges for a new project in the Amazon River basin, on a river that has no adequate series of historical discharges for studies of probability or of PMP and CMP.

\section{ACKNOWLEDGEMENTS}

The authors thank the Post-graduate Program in Civil Engineering (PPGEC) of the Federal University of Uberlândia (UFU) and the National Post-Doctoral Program (PNPD from
CAPES) for the post-doctorate grant provided to the first author and to NHC Brasil Consultores Ltda., for encouraging and offering technical and financial support for the development and presentation of this article. The authors also express thanks for comments and suggestions by the reviewers.

\section{REFERENCES}

ANA - AGÊNCIA NACIONAL DE ÁGUAS. Manual de estudos de disponibilidade hidrica para aproveitamentos hidrelétricos: manual do usuário. Brasília: ANA, 2009.

CASTELLARIN, A. Probabilistic envelope curves for design flood estimation at ungauged sites. Water Resources Research, v. 43, n. 4, p. 1-12, 2007. PMid:20300476. http://dx.doi.org/10.1029/2005WR004384.

COELHO FILHO, J. A. P.; NAGHETTINI, M.; PINTO, E. J. A. Curvas envoltórias probabilísticas para a estimação de cheias de projeto. Revista Brasileira de Recursos Hídricos, v. 16, n. 1, p. 83-96, 2011. http://dx.doi.org/10.21168/rbrh.v16n1.p83-96.

COSTA, J. E.; JARRETT, R. D. An evaluation of selected extraordinary floods in the United States. Washington: U.S. Geological Survey and Implications for Future Advancement of Flood Science Scientific, 2008. Report 2008-5164.

CREAGER, W. P.; JUSTIN, J. D.; HINDS, J. Engineering for dams. New York: Chapman and Hall, 1945. v. 1.

CRIPPEN, J. R. Envelope curves for extreme floods events. Journal of the Hydraulics Division, v. 108, n. 10, p. 1208-1212, 1982.

CUNNANE, C. Unbiased plotting positions: a review. Journal of Hydrology, v. 37, n. 3-4, p. 205-222, 1978. http://dx.doi. org/10.1016/0022-1694(78)90017-3.

ELETROBRÁS - CENTRAIS ELÉTRICAS BRASILEIRAS S.A. Guia para cálculo de cheia de projeto de vertedores. Rio de Janeiro: Centrais Elétricas Brasileiras S.A., 1987.

FILL, H. D.; STEINER, A. A. Estimativa do hidrograma instantâneo e da vazão máxima de enchentes a partir de vazões médias diárias. Revista Brasileira de Recursos Hídricos, v. 8, n. 3, p. 17-26, 2003. http:/ / dx.doi.org/10.21168/rbrh.v8n3.p17-26.

FRANCOU, J.; RODIER, J. A. Essai de classification des crues maximales observées dans le monde. Cabiers ORSTOM: Série Hydrologie, v. 4, n. 3, p. 19-43, 1967.

GRUBBS, F.; BECK, G. Extension of sample size and percentage points for significance tests of outlying observations. Technometrics, v. 14, n. 4, p. 847-854X, 1972. http://dx.doi.org/10.1080/0040 1706.1972.10488981. 
HERSCHY, R. World catalogue of maximum observed floods. Wallingford: IAHS, 2003. (IAHS Publication, 284).

JARVIS, C. S. Flood flow characteristics. Transactions of the American Society of Civil Engineers, v. 88, p. 985-1032, 1925.

KAVISKI, E. Uso de técnicas empíricas em regionalização hidrológica. In: X SIMPÓSIO BRASILEIRO DE RECURSOS HÍDRICOS, 3., 1993, Gramado. Anais... Porto Alegre: ABRH, 1993.

NEILL, C. R. Unusual canadian floods and the creager diagram. Canadian Journal of Civil Engineering, v. 13, n. 2, p. 255-257, 1986. http://dx.doi.org/10.1139/186-034.

SANGAL, B. P. Practical methods of estimating peak flow. Journal of Hydraulic Engineering, v. 109, n. 4, p. 549-563, 1983. http:/ /dx.doi. org/10.1061/(ASCE)0733-9429(1983)109:4(549).

SILVA, E. A.; TUCCI, C. E. M. Relação entre as vazões máximas diária e instantânea. Revista Brasileira de Recursos Hídricos, v. 3, n. 1, p. 133-151, 1998. http://dx.doi.org/10.21168/rbrh.v3n1.p133-151.

\section{Authors contributions}

Guilherme de Lima: Conceived the idea for the paper, performed data interpretation and analysis, verified the hydrologic analysis, contributed to the interpretation of the results, wrote the paper and revised it critically.

Silvana Susko Marcellini: Completed data acquisition and interpretation, performed the hydrologic analysis, contributed to the interpretation of the results, wrote the paper and revised it critically.

Charles Robert Neill: Contributed with the conception of the paper, provided support with the hydrologic analysis, contributed to the interpretation of the results, revised the paper critically and drafted the English version.

Márcio Ricardo Salla: Provided recommendations for the research, contributed significantly to the discussion of results, helped writing the paper, provided critical feedback and contributed to the final manuscript revisions and approval. 